\title{
Komunikasi Visual: Fantasi Tubuh Wanita Kelas Menengah di Instagram
}

\author{
Rama Kertamukti', Heru Nugroho ${ }^{2}$, dan S. Bayu Wahyono ${ }^{3}$ \\ 1,2Universitas Gadjah Mada \\ ${ }^{3}$ Universitas Negeri Yogyakarta
}

\begin{abstract}
ABSTRAK
Budaya manusia memberikan perwujudan kecantikan dalam doktrin rasis yang menyingkirkan heterogenitas perbedaan tubuh. Cantik menjadi standar representasi tubuh perempuan yang cantik dan ramping. Instagram memberikan ruang untuk wanita menjadi ramping dan cantik dengan berbagai sumber daya yang menegaskan perbedaan ramping dan gendut, serta menolak adanya representasi liyan terhadap tubuh. Tubuh gemuk akan dilekati oleh bayang-bayang obesitas sehingga gemuk menjadi sindrom bagi kebanyakan wanita. Instagram digunakan wanita kelas menengah untuk berfantasi mengenai tubuh yang dipresentasikan. Instagram dapat memanipulasi tubuh yang "nyata" mengikuti fantasi tubuh ketika memasuki logika Instagram yaitu visual artistik. Pengguna Instagram berfantasi dengan resources yang dimiliki Instagram, mereka berfantasi dengan tubuh ramping yang dipresentasikan di ruang online-feed Instagram. Penelitian ini mengkaji fenomena praktik wanita kelas menengah dalam memperlihatkan perubahan signifikan yang tidak ada batasan ruang dan waktu di ruang Instagram. Analisa yang dilakukan di sini dengan mendasarkan pada teori wacana tekstual. Wacana senantiasa melibatkan kondisi sosial dalam memproduksi dan menafsirkannya. Kondisikondisi terkait erat dengan tiga tataran organisasi sosial: situasi sosial, institusi sosial dan tataran sosial secara umum. Melihat wacana sebagai praktik sosial berarti mengkaji teks dalam hal ini visual di Instagram, menganalisis produksi, interpretasi serta mendalami hubungan teks, proses dan kondisi-kondisi sosial baik konteks situasional-institusional serta tatanan masyarakat. Dua akun yang diteliti@putrilellyana dan@ rosakusumaazhar menghadirkan wacana wanita mengenai tubuh. Kenyataan yang termanifestasikan dua akun ini bahwa konsumsi dan produksi dalam arena Instagram memberikan pembentukan pola realitas sosial. Instagram menjadi alat pembentuk konstruksi sosial, sekaligus pembentuk wujud kuasa kebenaran dalam realitas sosial, Instagram membuat ruang kendali keseragaman norma-norma kehidupan.
\end{abstract}

Kata-kata Kunci: Fantasi; instagram; kelas menengah; komunikasi visual; tubuh wanita

\section{Visual Communication: Fantasy of Middle Class Women's Body in Instagram}

\section{ABSTRACT}

Human culture gives the embodiment of beauty has instilled a racist doctrine that removes the heterogeneity of differences about the body. Instagram gives space for women to be sleek and beautiful with a variety of resources. This doctrine proliferates and begins to negate lean and obese differences and denies the existence of any other representation of the body. Fat body will be attached by the shadow of obesity so often fat become a frightening syndrome for most women. Instagram used middle-class women to fantasize about the body he presented. Instagram can manipulate the "real" body following the body's fantasies when entering Instagram logic which must produce an artistic visual. Therefore, this study examines the phenomenon of middle-class women's practice in showing significant changes that have no space and time limits in Instagram spaces. The analysis is done here by basing on the theory of textual discourse. Discourse always involves social conditions in producing and interpreting it. Conditions are closely related to the three levels of social organization: social situations, social institutions and the social level in general. Seeing the discourse as a social practice means reviewing texts in this case visually on Instagram, analyzing its production and interpretation and deepening the texts, processes and social conditions of both situational and institutional contexts as well as their societal order.The two accounts studied@putrilellyana and @rosakusumaazhar present a lot about women's discourse about their bodies. The facts manifested in these two accounts that consumption and production in the Instagram arena provide the formation of a pattern of social reality and Instagram can be an effective means of shaping social construction.

Keywords: Fantasy; instagram; middle class; visual communication; woman body

Korespondensi: Rama Kertamukti, M.Sn. Universitas Gadjah Mada, Bulaksumur, Caturtunggal, Kec. Depok, Kabupaten Sleman, Daerah Istimewa Yogyakarta 55281.Email: kawanrama@gmail.com 


\section{PENDAHULUAN}

Tindakan komunikasi adalah sebuah proses. Proses yang mencakup sumber, pesan dan penerima pesan. Ketika media berkomunikasi dengan khalayak maka sebuah proses berlangsung. Penting menjadi perhatian penciptaan dan pemahaman pesan tersebut berproses untuk dimaknai. Tindakan komunikasi mempunyai faktor dalam proses komunikasi yang berkelindan dalam memaknai isi dan representasi pesan. Pesan dapat diartikan menurut apa yang dikatakan oleh pesan itu ketika terlepas, karena tiap pesan mempunyai cara dan menyampaikan makna pada penerima pesan, tanpa terlepas dari konteks fisik ataupun sosial yang menghantarkan pesan tersebut, karena akan melibatkan makna. Makna sendiri diartikan memberi gagasan menyangkut ideide tentang masyarakat dan kepercayaan yang disirkulasikan melalui media (Burton, 2008). Proses pemaknaan juga mengalami perubahan dalam perkembangan teknologi komunikasi dengan penggunaan New media yang begitu konvergen. Teknologi tidak hanya berbasis teks, tetapi audio-visual, bahkan sangat interaktif.

Dinamika kehidupan sosial melalui mediasi teknologi new media telah menciptakan ruang dalam aktivitas kehidupan sosial yang sebelumnya beraktivitas dalam kebertubuhan tergantikan dengan aktivitas dalam ruang siber. Ruang siber memberikan peralihan aktivitas dalam ekonomi, transfer dan diseminasi pengetahuan, sampai moda interaksi.

Penggunaan media sosial sebagai salah satu ruang siber juga menimbulkan perubahan sosial, budaya dan aktivitas manusia. Instagram sebagai media sosial yang akan menjadi objek penelitian menawarkan budaya dan logika media yang baru bagi penggunanya. Media sosial ini berfokus pada berbagi konten dalam bentuk komunikasi visual, presentasi diri menjadi terepresentasikan dalam menyalurkan aktivitas dan penampilan fisik melalui fotografi. Instagram adalah ruang sosial teknologi yang berada dalam dimensi post-fenomenologis ruang siber. Media sosial adalah moda interaksi sosial yang tereduksi dan melampaui ruang kebertubuhan. Dalam dunia siber, tubuh terprogramkan, identitas terkonstruksi dalam wujud digital. Tubuh hadir secara audio visual dan kinestetis dalam ruang monitor. Media sosial mewujudkan tubuh-tubuh yang diunggah dalam dunia siber menjadi terkoneksi secara global. Dalam bahasa Bell:

Cyberspace: A new universe, a parallel universe created and sustained by the world's computers and communications lines. A world in which the global traffic of knowledge, secrets, measurements, indicators, entertainments, and alterhuman agency takes on form: sights, sounds, presences never seen on the surface of the earth blossoming in a vast electronic light (Bell, 2001).

Pendekatan filsafat teknologi Don Ihde, yang mengkaji fenomena teknologi dan bukan pada dampak teknologi, Ihde, memandang teknologi merupakan instrumentasi dalam dunia kehidupan. Teknologi sebagai "alat" manusia untuk memahami dunia. Alat mempengaruhi cara manusia mengalami dunia kehidupan. Manusia yang bertubuh mempersepsi dunia melalui teknologi. Ihde memberi titik bahwa penggunaan teknologi dalam wujud alat dapat mengubah pengalaman dan persepsi manusia. Persepsi manusia-dunia-kehidupan berubah bila teknologi dijadikan mediator antara manusia dan dunia kehidupannya (Lim, 2008).

Wanita dengan segala aktivitasnya juga melakukan hal yang sama. Wanita juga turut memaknai perkembangan teknologi ini dengan mengonsumsi media sosial untuk eksistensi diri. Saat ini kesuksesan seseorang tidak hanya ditunjukkan lewat pencapaian materi namun juga melalui tampilan fisik yang menarik dan dimediasikan melalui Instagram. Instagram adalah aplikasi photo sharing yang sangat populer karena memiliki nilai tambah yaitu efek-efek visual.

Instagram menggunakan mekanisme menyerupai Twitter, dimana pengguna bisa mengikuti orang lain dan para penggemar bisa mengikuti pengguna balik. Selanjutnya pengguna dapat bertukar komentar. Alasan paling tepat mengapa instagram populer adalah karena memiliki banyak efek instant yang menarik. Sebagian besar efek yang ada dalam aplikasi ini mampu mengubah foto apapun menjadi tampak lebih artistik (Jang, Han, Shih, $\&$ Lee, 2015). Di dalam dunia siber ruang-ruang sosial tetap tersedia seperti juga di dunia nyata (Bell, 2001). Ruang-ruang tersebut merupakan simulasi dari ruang sosial yang pengguna miliki di dunia nyata. Namun kedua ruang sosial 
tersebut memiliki karakteristik yang berbeda. Dalam ruang sosial dunia nyata pengguna akan memiliki kebersamaan yang bersifat sosial, solidaritas sosial dalam sebuah ruang atau tempat seperti kampung, dan di dalamnya pengguna selalu dimungkinkan umtuk dapat berkomunikasi secara face to face atau langsung tatap muka.

Sebaliknya, dalam simulasi ruang sosial pengguna tidak akan merasakan hal-hal tersebut. Pengguna hanya memerlukan imajinasi kolektif di dalam sebuah tempat yang imajiner juga yakni aliran bit-bit data dalam jaringan komputer. Ruang sosial dalam ruang siber merupakan simulasi dari ruang sosial dunia nyata layaknya sebuah permainan komputer atau games. Hal yang tidak pengguna sadari adalah adanya ruang-ruang dalam dunia cyber ini akan mempengaruhi ruang sosial di dunia nyata (Castells, 2010). Menjadi anggota jaringan sosial media tertentu biasanya berbanding lurus dengan latar belakang sosial yang dimiliki. Itulah yang diperoleh dari sebuah penelitian Pew Research Center yang dipublikasikan oleh Slate.fr. Menurut penelitian ini pendapatan orang mempengaruhi arah seorang remaja menjadi bagian dari sosial media. Dalam kesimpulannya bahwa remaja dari kalangan orang berpenghasilan sangat baik akan memilih berbagi foto di Instagram, sedangan mereka yang yang orang tuanya dari kelas rata-rata akan berbagi pesan di Facebook. Meski demikian, Facebook dikenal sangat disukai oleh remaja (71\%) dibandingkan dengan Instragram (52\%), Snapchat (41\%), dan Twitter (33\%) (Anderson \& Jiang, 2018).

Instagram adalah aplikasi media sosial yang diakses oleh semua kalangan, terutama yang memiliki perangkat memadai, karena operasional Instagram membutuhkan spesifikasi yang harus memadai karena berbasis pada foto (dengan pixel tinggi). Melalui Instagram, seseorang dapat mengunggah foto atau video, mempublikasikannya, dan terpampang pada galery pengguna yang lain. Dalam ruang Instagram pengguna Instagram disebut Instagramers (Herman, 2014)

Oleh karena itu tidak mengherankan apabila wanita masa kini beranggapan bahwa tuntutan berpenampilan prima di feed Instagram menjadi hal yang tidak terelakkan. Hal ini merupakan salah satu diantara banyak hal yang menandai terjadinya perubahan gaya hidup dan cara pandang manusia masa kini. Komunikasi visual tentang diri yang menarik menjadi salah satu penentu dalam kesuksesan dan keberuntungan dalamhidup. Media sosial Instagram menjadikan seseorang lebih ekspresif dalam menampilkan citra dirinya di hadapan publik melalui media online. Budaya siber tidak perlu menghadirkan tubuh secara nyata tetapi secara online, hal ini menjadikan wanita yang berada dalam pranata kelas menengah dan mengakses Instagram untuk berfantasi melalui presentasi komunikasi visual, penting untuk diteliti. Tan menentukan kelas menengah berdasarkan atas tingkat ekonomi. Tan membagi masyarakat dalam empat kelas yaitu kelas atas, kelas menengah, kelas pekerja, dan kelas miskin. Penelitiannya dapat disimpulkan bahwa Singapura termasuk dalam kelas menengah karena sedikitnya pengangguran, tingginya angka melek huruf, dan tingginya mobilitas sosial (Ningrum, Putri, \& Ekaputri, 2015).

Pengguna Instagram dalam hal ini wanita di kalangan kelas menengah kerap menebar unggahan dalam feed milik mereka. Mereka ingin memperlihatkan kelas yang mereka miliki yang terwakili oleh tubuh mereka yang ramping dan tertata, dalam istilah Bourdieu, kelas menengah dalam beraktivitas di Instagram ingin memperlihatkan distinction dan berupaya mencari basis sistem klasifikasi yang menstruktur persepsi bagaimana dunia sosial serta menentukan objek kesenangan estetis dalam struktur kelas sosial seperti pada kalangan kelas menengah (Bourdieu \& Nice, 1990). Dari pendapat Bourdieu jelas dikemukakan kelas menengah terbentuk karena akumulasi golongan-golongan sosial dalam sebuah pranata dalam masyarakat yang ditentukan oleh posisi tertentu dalam suatu proses produksi. kelas menengah di Indonesia pada umumnya adalah kelompok orang yang memiliki pendidikan tinggi, bekerja mengikut profesi dan kode etik masing-masing, mempunyai pendapatan memadai, dan memiliki prestige tinggi di dalam masyarakat.

Kelas menengah adalah kelompok orang yang meraih sukses karena memiliki disiplin tinggi, mandiri (independent), mematuhi ketentuan-ketentuan berlaku, dan memberi sumbangan berarti melalui karya mereka dibidang masing-masing (Heryanto, 2000). Kelas menengah sepertinya sangat menikmati apa yang mereka produksi dan unggah di 
feed mereka di Instagram. Praktik gaya hidup pun dipresentasikan dalam feed sehari-hari yang biasa mereka posting. Tidak hanya praktek pamer-produksi yang dilakukan oleh para pengguna Instagram kelas menengah, tetapi mereka juga mengonsumsi apa yang dipamerkan pengguna lainnya. Bahkan secara konsumtif Instagramers dapat membeli apa yang ditawarkan pengguna lainnya dan juga dapat menawarkan sesuatu di ruang galeri mereka untuk dikonsumsi pengguna lainnya. Keaktifan konsumen dalam mencari, memilih, dan menggunakan informasi sangat memungkinkan apabila mereka dapat berposisi sebagai produsen dalam menuliskan kembali informasi tersebut. Atas persepsinya pada informasi yang telah mereka dapat, konsumen secara radikal dapat memproduksi informasi baru setelahnya. Internet turut membentuk budaya baru, dalam kaitannya mengubah relasi pada konsumen yaitu mengonsumsi dan pada saat yang sama memproduksi apa yang dikonsumsi, dalam hal ini Paul du Gay dkk. menekankan jika pada proses produksi dan konsumsi saling berkaitan dan saling melingkupi (Du Gay, 1996).

Menurut Ariel Heryanto, penyokong utama gaya hidup adalah kelas menengah karena begitu intensifnya kelas ini berkonsumsi (Heryanto, 2000). Baudrillard melihat pola konsumsi masyarakat modern ditandai dengan bergesernya orientasi konsumsi yang semula ditujukan bagi "kebutuhan hidup", menjadi "gaya hidup". Baginya, hal tersebut tak lepas dari munculnya kelas menengah pasca-Perang Dunia II secara masif akibat diterapkannya konsep ekonomi Keynesian. Bagi Baudrillard, hal terkait menunjukkan betapa dewasa ini masyarakat lebih terpaku pada konsumsi simbol ketimbang kegunaan. Konsumsi memegang peranan penting dalam hidup manusia. Konsumsi membuat manusia tidak mencari kebahagiaan, tidak berusaha mendapatkan persamaan, dan tidak adanya intensitas untuk melakukan homogenisasi, manusia justru melakukan diferensiasi (perbedaan) yang menjadi acuan dalam gaya hidup dan nilai, bukan kebutuhan ekonomi (Lechte, 2008).

Data dari APJII 2017 tentang survei penetrasi pengguna internet di Indonesia memperlihatkan sebanyak 48,57\% pengguna internet adalah wanita dengan komposisi usia hampir $50 \%$ atau sebanyak $49,52 \%$ berusia 19-34 tahun, dan berada di kelas menengah.
Dan selalu aktif mengakses internet melalui perangkat smartphone/ tablet sebanyak 50,08\%. Penggunaan untuk media sosial sebanyak $89,35 \%$,jadi hampir semua pemilik smartphone/ tablet pada wanita mengakses media sosial seperti Instagram. Pemanfaatan untuk gaya hidup, $87,13 \%$ memperlihatkan internet untuk mengkonsumsi dan memproduksi gaya hidup (APJII, 2017).

Tubuh wanita kelas menengah dengan selera kelasnya diperlihatkan dalam tiap kesempatan di feed Instagram yang mereka miliki. Kontruksi wanita cantik yang diperlihatkan adalah langsing. "...the restrictions on masturbates hardly start in Europe, via the medium of families, an objecttivisation of sexuality allied to corporal persecution is established over bodies of children" (Foucault, 1980), lewat orang tua dan orang dewasa, anak-anak dijadikan objek analisa, keprihatinan, dan pengawasan serta kontrol dari konstruk sosial. Tubuh anak-anak menjadi titik konflik antara orangtua dan anak. Proses pendisiplinan ini berlangsung hingga dewasa.

Seperti kisah kebanyakan perempuan yang begitu resah melihat perutnya yang menggelambir setelah melahirkan, ada ketakutan suaminya tidak suka lagi dan berpaling, serta provokasi dari saudara laki-laki yang mengatakan bahwa perempuan gemuk tidaklah cantik. Penelitian Wolf menelusuri mitos kecantikan perempuan muda amerika yang mengidap anoreksia, yang mematuhi ideologi kecantikan, ramping dan langsing. Pemaknaan atas tubuh perempuan dijelaskan sebagai beikut, "karena dibudayakan, tubuh juga mengalami hierarki pemaknaan, tubuh yang indah, yang agak indah, dan tubuh yang tidak indah sama sekali" (Prabasmoro, 2006). Hierarki pemaknaan pada tubuh ini memaksa individu tidak lagi bebas dalam memandang tubuhnya sendiri. Tentu saja kancah publik menjadi medan wacana untuk menanamkan dan melestarikan kebenaran yang mereka usung. Akibatnya kesadaran masyarakat akan tubuhnya sendiri dianggap tidak valid dan tidak bisa dijadikan acuan dalam bersikap atas tubuhnya sendiri. Fenomena itu terjadi ketika mereka (wanita) mengakses media sosial seperti Instagram ini, ketika mereka memiliki tubuh yang tidak ramping, mereka akan berfantasi melalui Instagram sehingga apa yang dihadirkan di feed Instagram mereka 
adalah sosok yang cantik dan ramping. Ruang budaya yang dibangun bersama oleh para penggunanya, Cooley menegaskan bahwa perasaan diri bersifat sosial, karena maknanya dicipakan melalui bahasa dan budaya bersama dan karena hal itu berasal dari interpretasi subjektif individu atas penilaian orang-orang lain yang mereka anggap penting dan punya hubungan dekat dengan mereka (significant others) mengenai sikap dan tindakan individu tersebut (Handaningtias \& Agustina, 2017).

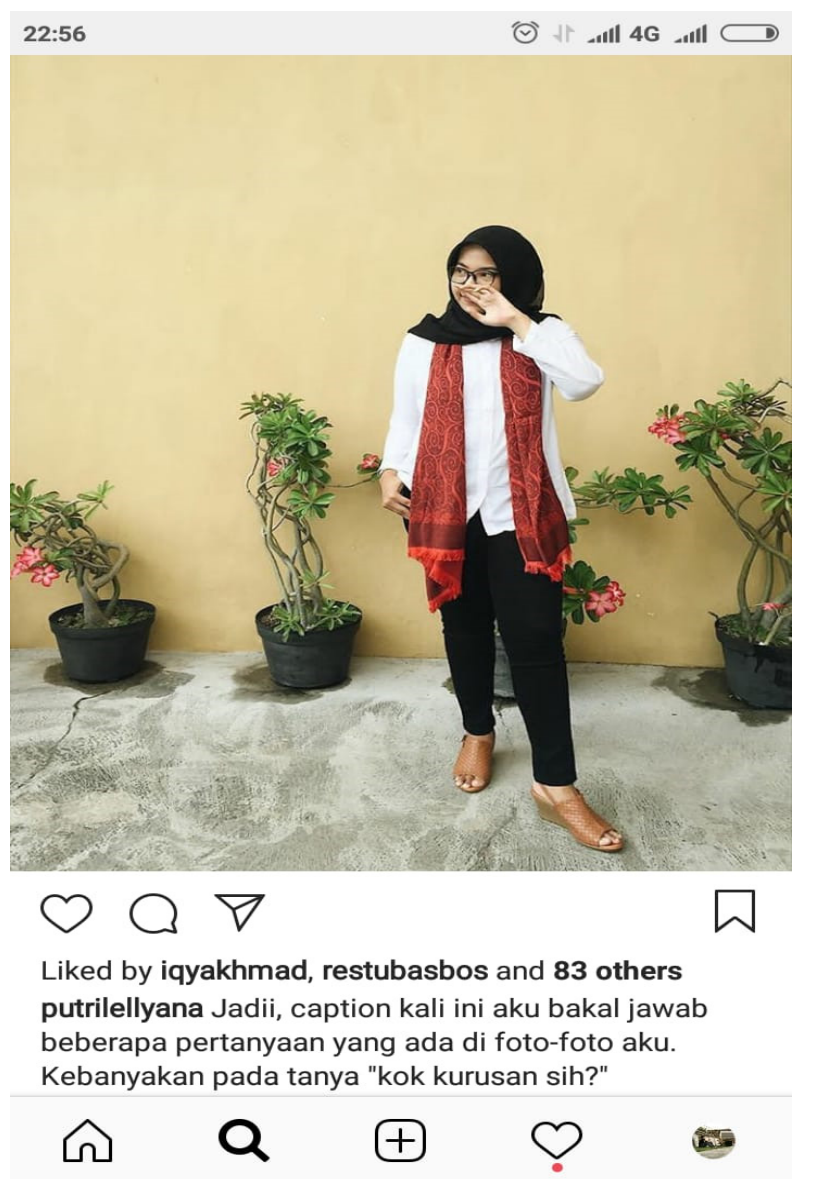

Gambar 1 Feed Akun@putrilellyana

Fantasi dan presentasi tubuh yang ramping menjadi ranah yang cukup intens dilakukan wanita di ruang Instagram seperti gambar diatas. Fantasi sendiri berarti kemampuan jiwa untuk membentuk tanggapan-tanggapan atau bayangan-bayangan baru (Thahir, 2014). Dengan pernyataan itu fantasi dapat memberi kekuatan pada manusia dengan dapat melepaskan diri dari keadaan yang dihadapinya dan menjangkau ke depan, ke dalam keadaankeadaan yang akan datang. Fantasi sebagai kemampuan jiwa manusia dapat terjadi apabila individu betul-betul menyadari akan fantasifantasinya. Misal seorang pelukis yang sedang menciptakan lukisan dengan kemampuan fantasinya, seperti juga seorang pemahat yang sedang memahat arca atas dasar daya fantasinya (Thahir, 2014). Secara tidak sadar individu telah dituntut oleh fantasinya sendiri. Keadaan semacam ini banyak dijumpai pada Anakanak. Anak sering mengemukakan hal-hal yang bersifat fantastis, sekalipun tidak ada niat atau maksud dari anak untuk berdusta. Misal seorang anak memberikan berita yang tidak sesuai dengan keadaan senyatanya, sekalipun ia tidak ada maksud untuk berbohong. Dalam hal semacam ini anak dengan tidak disadari dituntun oleh fantasinya (Thahir, 2014), jadi secara umum fantasi merupakan aktivitas yang menciptakan.

Dalam Instagram fantasi mendapat medianya, fantasi berkembang dalam pola visual yang memang dikehendaki. Pola fantasi itu; Fantasi yang menciptakan yaitu merupakan bentuk atau jenis fantasi yang menciptakan sesuatu. Misal seorang ahli mode pakaian menciptakan model pakaian atas dasar daya fantasinya; seorang pelukis menciptakan sesuatu lukisan atas daya fantasinya. Fantasi yang dituntun atau yang dipimpin yaitu merupakan bentuk atau jenis fantasi yang dituntun oleh pihak lain. Misal seseorang yang melihat visual, orang ini dapat mengikuti apa yang dilihatnya dan dapat berfantasi tentang keadaan atau tempattempat lain dengan perantaraan visual itu, sehingga dengan demikian fantasinya dituntun oleh visual tersebut (Thahir, 2014). Dilihat dari caranya orang berfantasi, fantasi dapat dibedakan atas fantasi yang mengabstraksi, yang mendeterminasi dan yang mengombinasi. lalu, Fantasi yang mengabstraksi yaitu cara orang berfantasi dengan mengabstraksikan beberapa bagian, sehingga ada bagian-bagian yang dihilangkan. Kemudian, Fantasi yang mendeterminasi yaitu cara orang berfantasi dengan mendeterminasi terlebih dahulu. terakhir Fantasi yang mengombinasi yaitu orang berfantasi dengan eara mengombinasikan pengertian-pengertian atas bayangan-bayangan yang ada pada individu bersangkutan. Fantasi apabila dibandingkan dengan kemampuankemampuan jiwa yang lain, fantasi lebih bersifat subjektif. Dalam orang berfantasi bayanganbayangan atau tanggapan-tanggapan yang telah ada dalam diri orang memegang peranan yang sangat penting (Thahir, 2014).

Menelusuri studi terdahulu yang 
mengambil topik presentasi diri di Instagram ada yang menjadi acuan penting dalam penelitian saya karena memiliki konsep yang sama yaitu presentasi diri di Instagram. Analisis di dalamnya juga dapat memberikan gambaran mengenai presentasi diri sebagai Pada dasarnya setiap individu melakukan berbagai cara untuk mempresentasikan dirinya kepada orang lain, individu akan mempresentasikan dirinya dengan cara verbal dan nonverbal pada saat berinteraksi dengan orang lain sebagai impression management atau manajemen kesan, sebuah tindakan menampilkan diri yang dilakukan oleh seorang individu untuk mendapatkan citra yang diharapkan.

Salah satu studi survei menarik tentang Narsisme yang direalisasikan dalam Instagram (Rahmanita, 2015). Fokus penelitiannya tentang kecenderungan narsistik antara laki-laki dan perempuan pengguna jejaring sosial Instagram. Ada beberapa hal yang cukup penting dapat menjadi pemikiran adalah Keinginan seseorang untuk menyalurkan aktivitas dan penampilan fisiknya melalui fotografi berhubungan dengan kecenderungan narsistik yang dimiliki oleh orang tersebut, dia membanggakan dirinya sendiri atau mereka yang sering berfoto ria untuk dipamerkan kepada orang lain, Sikap narsisme ini berhubungan dengan self-views (pandangan diri) yang melambung tinggi dan positif pada sifat-sifat seperti inteligensi, kekuatan, dan keindahan fisik. Dan aktivitas memanfaatkan individu lain untuk kepentingan diri sendiri dan hanya menunjukkan sedikit empati kepada individu lain.

Kecenderungan seseorang untuk menggugah suatu gambar atau foto dengan tujuan untuk mencari perhatian orang lain (need for admiration), merupakan salah satu ciri seseorang dengan kecenderungan narsistik. Biasanya orang dengan kecenderungan narsistik ini juga akan diikuti dengan ciri-ciri lain, seperti arrogance, self-centeredness, greed, dan lack of empathy. Jumlah partisipan dalam penelitian yang dilakukan Ulya Rahmanita ialah 120 orang. Laki-laki berjumlah 60 orang dan perempuan berjumlah 60 orang (Rahmanita, 2015).

Dari hasil survei yang dilaku kan dicatat beberapa yang sangat menonjol dalam aktivitas di Instagram, yaitu: Pandangan yang dibesar-besarkan mengenai pentingnya diri sendiri, arogansi. Terfokus pada keberhasilan, kecerdasan, kecantikan diri. Percaya bahwa dirinya spesial dan unik sehingga hanya dapat dipahami atau berasosiasi dengan orang lain yang spesial atau yang berstatus tinggi. Kebutuhan ekstrem untuk dipuja. Perasaan kuat bahwa mereka berhak mendapat segala sesuatu. Kecenderungan memanfaatkan orang lain. Iri pada orang lain dan percaya bahwa orang lain iri terhadap dirinya. Lemah dalam empati; tidak mampu untuk melihat atau mengidentifikasi perasaan dan kebutuhan orang lain; dan, Menunjukkan perilaku atau sikap yang sombong dan angkuh.

Penelitian untuk mengungkap bagaimana wanita mempresentasikan dirinya di media sosial telah dilakukan juga dalam Riset Social Comparisons on Social Media: The Impact of Facebook on Young Women's Body image Concerns and Mood yang membahas tentang bagaimana penggunaan Facebook dikaitkan dengan kekhawatiran citra tubuh, terutama jika pengguna sedang terlibat dalam beberapa jenis kegiatan di media sosial, seperti membuat perbandingan penampilan mereka dengan orang lain. citra tubuh adalah sebagian dari konsep diri yang berkaitan dengan sifat-sifat fisik dan merupakan evaluasi individu mengenai dirinya sendiri (Fardouly \& Vartanian, 2017). Kesadaran dan penerimaan individu terhadap tubuhnya merupakan aspek utama dari citra tubuh dan itu citrakan dalam foto-foto mereka di Facebook.

Mendefinisikan citra tubuh sebagai gambaran mental seseorang terhadap bentuk dan ukuran tubuhnya dibahas dalam penelitian ini yang dilakukan wanita tanpa batasan kelas. Apa yang dia pikirkan dan rasakan belum tentu benar-benar dapat merepresentasikan keadaan yang sebenarnya, namun lebih merupakan hasil penilaian diri yang subjektif. Itulah yang dirasakan ketika menggunakan Facebook.

Sedangkan penelitian tentang Instagram yang dilakukan oleh peneliti mengkaji bagaimana kegelisahan wanita atas keinginannya bertubuh baik secara sosial, mereka ingin mengkomunikasikan secara visual bahwa cantik itu ramping dan tinggi. Objek akun Instagram yang diteliti adalah secara offline pemilik akun Instagram sudah dikenal terlebih dahulu oleh peneliti, sehingga mempermudah peneliti memberikan alasan memilih akun tersebut. Yang pada kenyataannya tubuh yang dihadirkan secara offline-dunia nyata dan online berbeda, disebabkan dalam dunia online 
sumberdaya Instagram dapat memanipulasi tubuh yang "nyata" mengikuti fantasi tubuh ketika memasuki logika Instagram yang harus menghasilkan visual yang artistik. Bagaimana pemilik akun berfantasi dengan resources yang dimiliki Instagram, mereka berfantasi dengan tubuh ramping yang dipresentasikan di ruang online-feed Instagram yang tidak dimiliki di dunia nyata. Oleh karena itu, penelitian ini mengkaji fenomena praktik wanita kelas menengah dalam memperlihatkan perubahan signifikan yang tidak ada batasan ruang dan waktu di ruang Instagram. Bagaimana kelas menengah bertarung dalam menampilkan bahkan merepresentasi "tubuh" mereka yang ramping di dunia siber dan menjadikan mereka masyarakat tontonan.

\section{METODE PENELITIAN}

Analisa yang dilakukan berdasarkan pada teori wacana tekstual. Dengan rujukan pada Fairclough yang memandang teks, atau dalam hal ini visual, sebagai teks yang merupakan sebagian dari keseluruhan proses interaksi sosial sebagai sebuah wacana (Fairclough, 1989). Analisa wacana mencakup kajian produktif dan interpretatif. Fairclough meyakini bahwa analisa semacam ini harus juga menyandarkan pada faktor-faktor penentu secara sosial. Artinya proses produksi dan interpretasi sebuah wacana tidak akan lengkap, bila pengaruh-pengaruh yang mengarahkannya tidak dilibatkan dalam proses kajian.

Wujud wacana terbentuk atau ditentukan oleh sesuatu di luar itu, yakni masyarakat sebagai faktor di luar teks-bahasa yang merupakan wujud paling nyata dari apa yang disebut wacana. Wacana baik dalam produksi maupun interpretasi yang merupakan fenomena sosial. Dua proses tersebut berlangsung dalam pikiran manusia yang tidak lain merupakan para anggota masyarakat. Bagaimana pikiranpikiran itu memproduksi wacana, serta menginterpretasikannya selanjutnya ditentukan oleh relasi dan kontestasi antara pikiran-pikiran yang melekat dalam tiap diri individu. Bila demikian, lanjut Fairclough wacana senantiasa melibatkan kondisi sosial dalam memproduksi dan menafsirkannya (Fairclough, 1989), wacana ini berada dalam dunia Instag,ram yang menampilkan identitas virtual.

Terdapat pandangan yang mendukung pernyataan bahwa di dalam diri setiap orang memiliki "kekuasaan" untuk menentukan pandangan hidupnya sendiri, untuk menyusun ideologinya sendiri, dan untuk merangkai identitas sendiri yang unik, yang notabene sejalan dengan kehidupan postmodern yang ditawarkan internet dalam realitas virtualnya. Identitas menjadi suatu hal yang dipertanyakan ketika hidup dalam dunia maya. Identitas merupakan konstruksi refleksi atau gambaran hidup individu baik yang dimiliki secara alami maupun terbentuk melalui proses kehidupan. Identitas memberikan individu tentang siapa dirinya, bagaimana hubungan dengan orang lain dan posisinya dalam kehidupan sosial. Identitas dalam dunia maya sulit untuk dilacak kecuali bagi orang-orang yang memiliki kedekatan secara personal di ruang offline, meski terkadang ketika komunikasi dilanjutkan di dunia maya, identitas menjadi suatu kesangsian.

Wacana sebagai praktik sosial berarti mengkaji teks, dalam hal ini visual di Instagram, menganalisis produksi dan interpretasinya serta mendalami hubungan teks, proses dan kondisikondisi sosial baik konteks situasional maupun institusional serta tatanan masyarakatnya (tiga tataran organisasi sosial: situasi sosial, institusi sosial dan tataran sosial secara umum). Akun Instagram yang menjadi objek penelitian ini adalah akun yang pemiliknya secara offline dikenal peneliti, sehingga produksi wacana visual yang dipresentasikan dan interpretasi visual serta kontestasi pemikiran yang ada diharapkan akan mempermudah peneliti untuk menganalisis wacana visual yang hadir. Alat komunikasi manusia pada hakikatnya tidak hanya berupa bahasa tulisan, lisan atau bahasa isyarat melainkan juga bahasa rupa yang merupakan tanda komunikasi simbolik atau komunikasi visual. Bahasa rupa memang tidak memiliki kaidah gramatika seperti halnya bahasa lisan atau bahasa tulisan sehingga setiap orang yang melihat kadang memiliki pendapat dan penafsiran yang berlainan (Kertamukti, 2013).

Wacana sebagai bentuk praktik sosial, lebih daripada aktivitas individu atau merefleksikan sesuatu dalam hal ini foto atau gambar di akun instagram informan. Dalam artian wacana dipengaruhi oleh kondisi sosial, akan tetapi kondisi sosial juga dipengaruhi oleh wacana (Fairclough, 1989). Penelitian ini ingin mengkaji foto informan dalam menghadirkan representasi, 
relasi, dan identitas. Objek penelitian adalah dua Informan@rosakusumaazhar dan @ putrilellyana, mereka adalah kelas menengah, informan pertama bekerja sebagai Penyiar TV dan Radio dan informan kedua adalah PNS Dinas PU, dengan strata sedang menjalani pendidikan S2. Pada penelitian ini, terdapat tiga metode pengumpulan data yang digunakan, yaitu pengumpulan foto di akun Instagram informan, wawancara, dan studi pustaka.

Pada teknik analisis data, Fairclough mengenalkan kerangka menganalisis bahasa media, bahwa bahasa media merupakan elemen penting pada proses kontemporer perubahan sosial dan kultural. Analisis bahasa teks media, menurut Fairclough, dapat menjawab tiga pertanyaan mengenai output media, yaitu; (1) bagaimana dunia (peristiwa, hubungan, dll.) direpresentasikan, (2) identitas apa yang dibentuk pada mereka dalam keterlibatan di suatu cerita, (3) relasi apa yang dibentuk antara mereka yang terlibat (Fairclough, 2013).

\section{HASIL DAN PEMBAHASAN}

Manusia sebagai makhluk sosial (homo homini socius). Istilah tersebut pertama kali dicetuskan, menegaskan manusia sangat membutuhkan komunikasi, bukan hanya untuk bertahan hidup tetapi juga untuk memuaskan hasratnya yang ingin berbagi perasaan, pendapat, dan pemikiran. Aktivitas selalu bergerak dinamis, kehidupan sosial selalu berkembang dan selalu memberikan perubahan. Perubahan tersebut karena need and wants manusia yang beradaptasi dengan apa yang ada di sekelilingnya. Teknologi Internet atau teknologi baru ini adalah hasil dari dinamika manusia yang membutuhkan kualitas hidup yang lebih baik dan bersinergi dengan gerak kehidupannya, dan teknologi ini semakin mempermudah aktivitas yang manusia lakukan. Instagram memberikan solusi terbaik dalam hal wanita dapat mempresentasikan dirinya dengan sangat baik-artistik.

Akun yang diteliti sebanyak 2 akun yang keduanya memiliki tubuh yang dalam konstruksi sosial dimaknai bertubuh "gemuk", dalam persepsi media yang terbentuk gemuk adalah tidak indah, Gemuk itu tidak indah dan menyebabkan penurunan rasa percaya diri dalam penampilan fisik. Konstruksi sosial di masyarakat kita mengurai pada bentuk tubuh yang ideal adalah langsing (langsing=cantik), tidak kelebihan lemak pada bagian-bagian tubuh (proporsional), perut datar, payudara kencang, pinggang berlekuk-liku, pantat sintal. Perempuan memang selayaknya bertubuh indah, karena bentuk fisik yang menarik merupakan kebanggaan perempuan dalam bermasyarakat dan berkeluarga (Melliana, 2006).

Tentang konstruksi sosial terhadap tubuh, Dani Cavallaro mengutarakan bahwa "membingkai" tubuh adalah cara vital dalam melanggengkan struktur kekuasaan, pengetahuan, makna dan hasrat (Cavallaro, 2000). Dalam masalah ini "cantik" nyatanya memilah representasi secara berbeda terhadap citra tubuh, dalam hal ini mendiskriminasikan bentuk lain dari tubuh di luar kehendak body image sehingga estetika nilai kecantikan yang digerakkan akan menganut arus utama yang terkonstruksi dan mendominasi yaitu kulit putih dan bentuk tubuh langsing dengan berbagai identifikasi makna yang selalu terbenam dalam makna-makna tersebut. Dua akun ini dalam mengakses Instagram menggunakan gawai yang cukup baik, kepemilikan gawai akun@putrilellyana menggunakan Oppo dan @rosakusumaazhar menggunakan iPhone, dengan kualitas lensa yang sangat baik dan menggunakan aplikasi editing foto untuk menambah, memperbaiki foto yang sudah diambil dan akan diunggah di Instagram.

Penelitian ini menganalisis unggahan akun@putrilellyana. Unggahannya selalu mempertimbangkan aspek sudut dan pencahayaan yang terfokus pada tubuh. Seperti foucauldian mewacanakan tentang tubuh bahwa konstruksi sosial yang di belakangnya berdiri kuat ideologi kapitalisme dan konsumerisme melalui media tubuh akan diusung selalu dengan tema kecantikan dan kesehatan menawarkan berbagai cara, strategi dan juga produk yang digunakannya untuk mendisiplinkan tubuh untuk tampak "menarik". Instagram memberikan ruang untuk tubuh menjadi fantasi yang diinginkan pengguna Instagram. Dalam galeri yang dimiliki@putrilellyana hadir foto-foto dirinya dengan berbagai gaya yang menampilkan segala aktivitasnya dan hampir semuanya menampilkan seluruh tubuh.

Harapan keinginan untuk memperlihatkan tubuh yang ideal termanifestasi dengan berbagai angle foto yang ditampilkan semuanya mewacanakan tubuh yang ramping dan energik. 


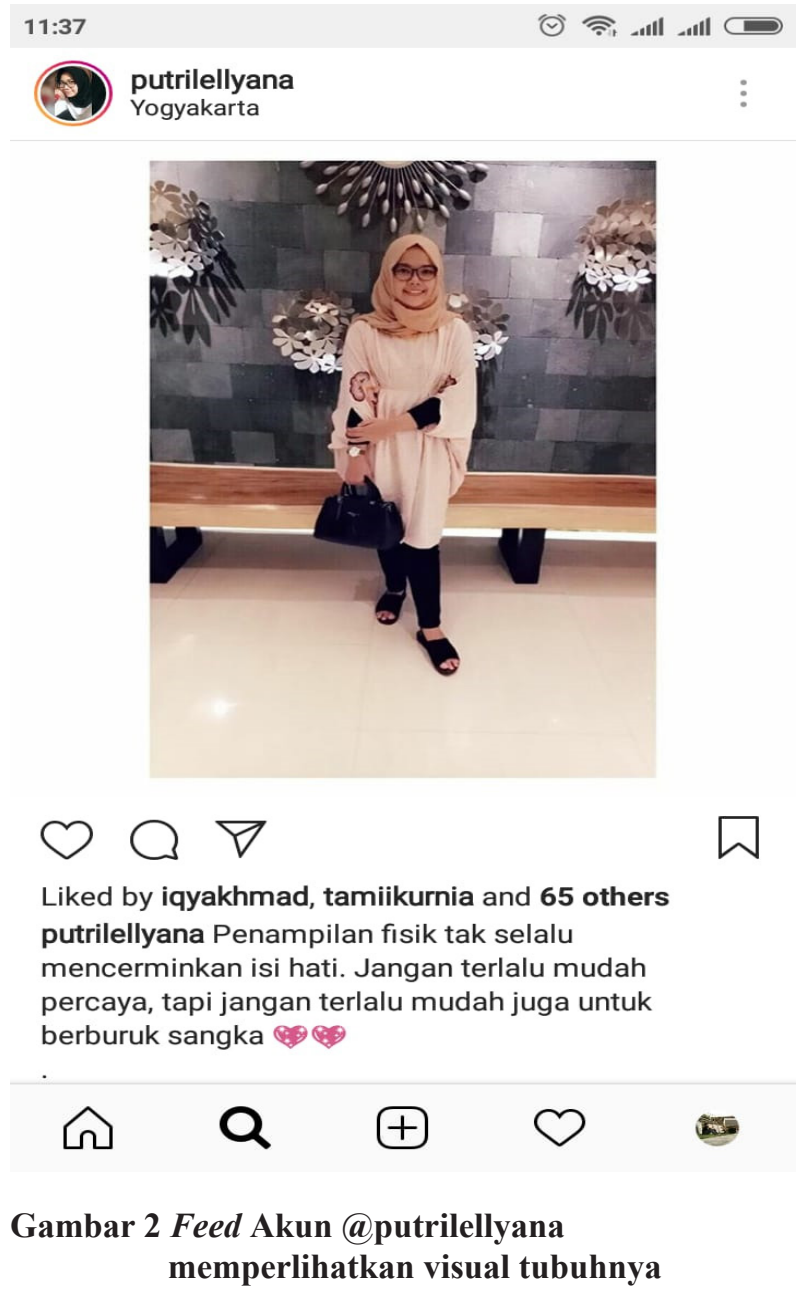

Putrilellyana berfantasi terhadap tubuhnya di Instagram, daya fantasinya untuk merampingkan tubuhnya pada komunikasi yang dipresentasikan secara visual dilakukan dengan menggunakan editing foto sebelum di unggah di Instagram. Smartphonenya sangat mendukung untuk mengedit foto yang diinginkan, dengan menggunakan aplikasi editing foto, Spring. Spring dikenal sebagai aplikasi editing foto yang dapat mengkreasi agar tubuh tampak lebih tinggi. Aplikasi ini memberikan fitur untuk meninggikan badan, dan beberapa fitur yang ada di spring menawarkan mengatur ukuran kepala dan leher serta melangsingkan tubuh. Aplikasi yang dibuat oleh Kim Taewan telah diunduh lebih dari 4 juta pengguna di 217 negara. Spring dapat dengan mudah diunduh di Google store atau Playstore. Visual yang disajikan pada feed @ putrilellyana memberikan rasa kecantikan yang difantasikannya tidak bisa dilepaskan dari citra tubuh yang dikomunikasikan dalam menampilkan kecantikan dan sisi seksualitasnya. Kecantikan yang diunggah melalui visual di akunnya menampilkan bentuk fisik yang difantasikan. Fantasi ramping yang berbeda dengan tubuh offlinenya didapat dari bagaimana angle kamera ketika mengambil foto. Posisi berdiri secara pose chin up, mengangkat dagu cenderung ke atas sehingga menghasilkan rahang yang lebih defined kurus. Produksi makna ramping pun dilakukan dengan meletakkan lengan menutupi pinggang atau perut. Mempercayai bahwa ketika berfoto dengan segala aktivitas yang dilakukan memperlihatkan ruang tubuh ramping bagi Putrilellyana. Narasumber adalah pegawai Dinas lingkungan hidup yang selalu sibuk dengan segala aktivitas di kantor, bahkan akun Instagramnya tidak menggunakan fitur private sehingga siapapun bisa mengakses atau melihat ruang feed yang dimiliki putri. Alasan Putri mengapa dia tidak menggunakan fitur private di akun Instagramnya adalah karena,“... aku hanya ingin berbagi kebahagiaan hidupnya didalam ruang-ruangnya dalam aktivitas sehari-hari". Hampir semua komunikasi visual dengan unggahan foto-foto di feed Putrilellyana memperlihatkan tubuhnya dengan berbagai pose, dari full body hingga setengah badan. Instagram menjadi pilihan menarik karena dapat mengkontruksikan diri sebagai bentukan protes terhadap identitas mereka yang ditolak pada dunia nyata. Menurut Giese, "identity in cyberspace can thus be fluid, ephemeral and empowering because people can choose how they are represented. Users literally became the authors of their lives" (Naseh, 2016)

Kemampuan sumber daya berupa fiturfitur yang difasilitasi Instagram dimaksimalkan dalam tiap foto yang diunggah, semua foto memaksimalkan kemampuan memberikan nilai artistik dalam fotonya. Informan dalam mengakses Instagram menggunakan gawai yang cukup baik, dengan kualitas lensa yang sangat baik dan menggunakan aplikasi editing foto untuk menambah, memperbaiki foto yang sudah diambil dan akan diunggah di Instagram. Seperti@Putrilellyana menggunakan OPPO

Praktik pengalaman mengadaptasi mitos kecantikan yaitu cantik dan ramping jelas tampak di unggahan yang dilakukan Putrilellyana, yang rentang unggahan fotonya ditiap minggu selalu ada unggahan baru dan yang lama diarsipkan olehnya, jadi terlihat selalu baru tampilan feednya. Mitos kecantikan mendorong wanita kelas menengah yang latar belakang mempunyai aktivitas dan kemampuan ekonomi untuk selalu ditampilkan dalam ruang sosial yang dimediasi 
Instagram. Pengaruh kultural (Jawa) dalam diri Putrilellyana yang kuat memosisikan dirinya untuk melihat dirinya sebagai objek keindahan. Keterkaitan timbal-balik antara kecantikan dan keindahan melahirkan pandangan seksual yang kritis terhadap diri wanita sendiri. Ramping adalah ketika berat badan terlihat lebih langsing dan diri merasa lebih seksi dan menarik secara pandangan lawan jenis, dan ini ditekankan dengan hadirnya lawan jenis yang berdampingan dalam fotonya.
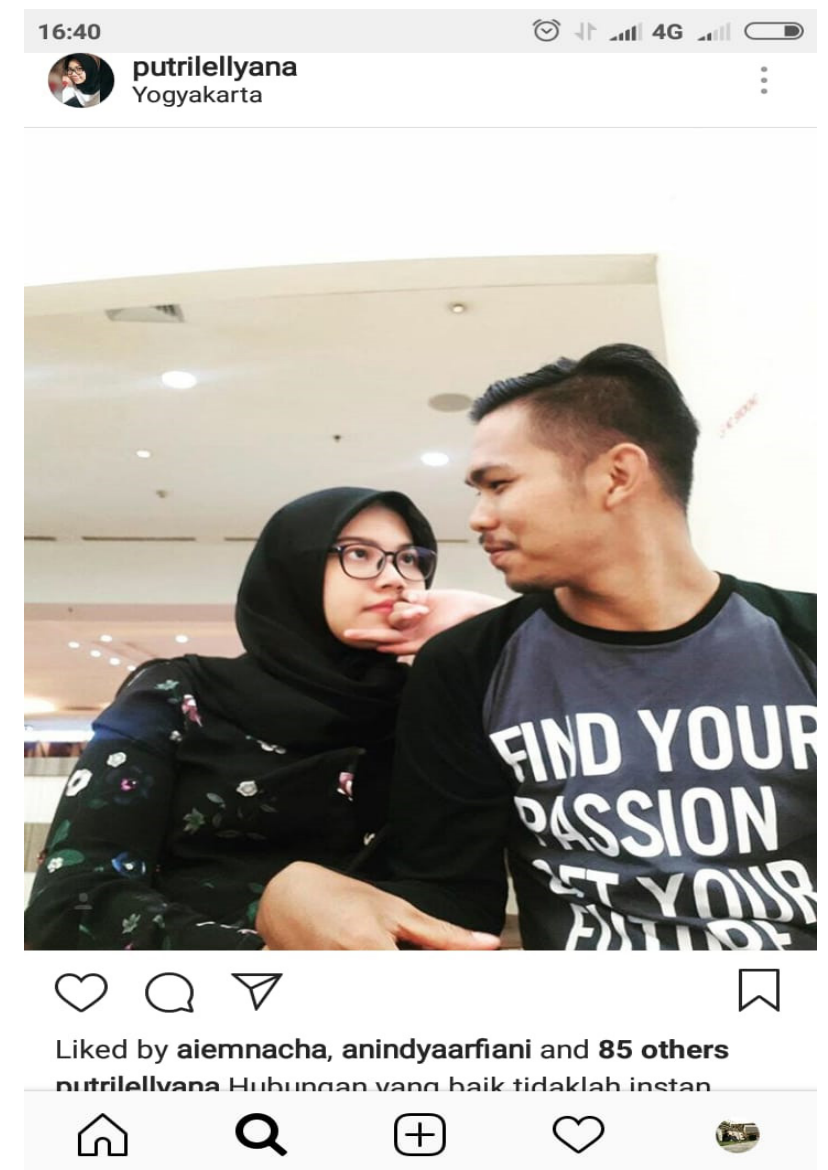

Gambar 3 Feed Akun@putrilellyana memperlihatkan dengan pasangan

Caption yang dibuat oleh akun Instagram dari@putrilellyana yang mengutarakan "Penampilan fisik tak selalu mencerminkan isi hati. Jangan terlalu mudah percaya, tapi jangan terlalu mudah juga untuk berburuk sangka", bahkan dipertegas dengan caption yang panjang tentang persepsinya pada tubuh. Caption ini mempertegas bahwa wanita wajib merawat tubuh dan penampilan fisik secara keseluruhan, karena bentuk tubuh yang diperlihatkan pada publik akan menjadi perhatian, Putri memperlihatkan berat badan adalah permasalahan yang paling disorot di masyarakat. Keinginan atau hasrat melakukan sebuah ritual, dengan berbagai cara, dan aktivitas dalam memelihara tubuh dengan tujuan menjaga kecantikan wajah, peremajaan kulit, dan bentuk tubuh dengan makna melakukan intensi perawatan tubuh. Persepsi tubuh yang dibangun media seperti visualisasi yang muncul dalam galeri-galeri di Instagram menampilkan ukuran tubuh wanita yang ideal dengan banyak followers, hal ini yang menarik dan seperti menjadi persepsi tunggal bahwa apa yang tertampil di Instagram adalah tubuh dengan ukuran yang sudah ditetapkan. Bentuk tubuh yang ditawarkan Instagram dengan nilai "idealnya" menjadikan wacana ketidakpuasan bagi wanita yang tidak memiliki tubuh "ideal" yang ditampilkan di galeri-galeri Instagram. Arti ketidakpuasan di sini adalah perasaan tidak puas terhadap bentuk dan ukuran tubuh yang dimiliki karena kesenjangan antara persepsi pengguna Instagram terhadap ukuran tubuh yang ideal dengan ukuran tubuh yang dimiliki pengguna Instagram. Adanya penilaian negatif terhadap tubuh yang tidak ramping, adanya penilaian tubuh yang tidak ramping adalah beban bagi wanita yang memilikinya.

\begin{tabular}{|c|c|}
\hline \\
\hline \multicolumn{2}{|c|}{$\begin{array}{l}16: 50 \\
\text { putrilellyana Jadii, caption kali ini aku bakal jawab } \\
\text { beberapa pertanyaan yang ada di foto-foto aku. } \\
\text { Kebanyakan pada tanya "kok kurusan sih?" }\end{array}$} \\
\hline \multicolumn{2}{|c|}{$\begin{array}{l}\text { Ada yang bilang karna jatuh cinta, haha. Tapii kurang } \\
\text { tepat sih. Lebih tepatnya udah hampir } 2 \text { tahun ini aku } \\
\text { diet. Ganti-ganti juga metode dietnya. }\end{array}$} \\
\hline \multirow{3}{*}{\multicolumn{2}{|c|}{$\begin{array}{l}\text { Singkat aja ya..?? Berat badan awal sebelum diet itu } \\
86 \mathrm{~kg} \text { (kalo mau tau bentuknya scroll aja foto-foto } \\
\text { aku, disitu ada pas BBku } 86 \mathrm{~kg} \text { ). Diet awal yang } \\
\text { kujalani itu diet mayo. Pasti kalian taulah yaa metode } \\
\text { diet mayo itu kayak gimana. Setelah beberapa hari } \\
\text { berjalan, aku nggak sanggup dan hasilnya cuma turun } \\
1 \mathrm{~kg} \text {, akhirnya batal. }\end{array}$}} \\
\hline & \\
\hline & \\
\hline \multicolumn{2}{|c|}{$\begin{array}{l}\text { Diet kedua aku pake OCD, itupun juga cuma bertahan } \\
2 \text { hari dan aku nggak sanggup, akhirnya batal. (Gada } \\
\text { hasil jugak, hehe. Yaiyalah baru } 2 \text { hari) }\end{array}$} \\
\hline \multirow{2}{*}{\multicolumn{2}{|c|}{ 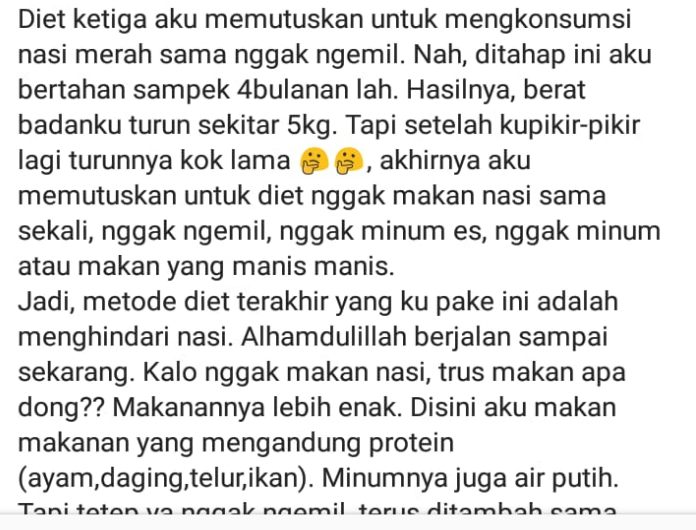 }} \\
\hline & \\
\hline & \\
\hline
\end{tabular}

Gambar 4 Caption persepsi @putrilellyana tentang tubuh 
Caption@putrilellyana@tetap memperlihatkan cantik dan langsing adalah dua kata yang menggambarkan sosok wanita yang menarik. Perempuan dikonstruksikan sebagai makhluk yang cantik, identik dengan keindahan. Menjadi "wanita" berarti menjadi cantik, itu ditegaskan dalam caption-caption yang dibuat@putrilellyana. Kelas menengah selalu mengonsumsi makna ini dalam aktivitas kehidupannya, karena ekonomi yang dimiliki dapat memperkuat fantasi terhadap kecantikan. Fantasi@putrilellyana itu memproduksiwacana ramping, serta menginterpretasikannya dengan foto-foto yang ditampilkannya dengan berbagai editing dan filter dari aplikasi hingga sesuai dengan persepsi yang ia ingin presentasikan, dan follower-nya sependapat. Arena dari ruang Instagram antara yang memproduksi dan mengonsumsi makna mempunyai interpretasi wacana ramping sama sehingga menghasilkan kesepakatan makna. Tafsir dominan atas ramping menjadi hal yang sangat memaknai dari visual-visual yang diunggah @putrilellyana.

Akun yang kedua@rosakusumaazhar, seorang broadcaster profesional, hampir seluruh unggahan di ruang feed-nya mempresentasikan diri dan tubuhnya. Wanita muda yang energik dan selalu dalam aktivitas profesional, dihadirkan dalam feed @rosakusumaazhar untuk memvisualisasikan dirinya. identitas merupakan sesuatu yang terbentuk secara representatif, bukanlah sesuatu yang sudah ada. Identitas memberikan gambaran siapa dirinya, bagaimana hubungannya dengan orang lain, dan posisinya dalam kehidupan sosial. "identity is about sameness and difference, about the personal and the social, about what you have in the common with some people and what differentiates you from others" (Weeks, 2002).

Rosa adalah gambaran wanita masa yang didambakan konstruksi sosial masyarakat saat ini dengan segala aktivitasnya. Dalam budaya di Indonesia yang patriarki dan konstruksi tentang kecantikan adalah ramping dan tinggi menjadi kebenaran utama yang dipertahankan. Budaya patriarki ini membangun persepsi yang terinternalisasi oleh wanita, menjadikan tubuh langsing dan seksi sebagai ukuran objektifikasi bagi tujuan eksistensi. Apalagi Rosa sebagai ibu rumah tangga, dalam konstruksi masyarakat penilaian kualitas seksual serta merta mengorganisasi keintiman didasarkan pada bentuk tubuh dan peningkatan
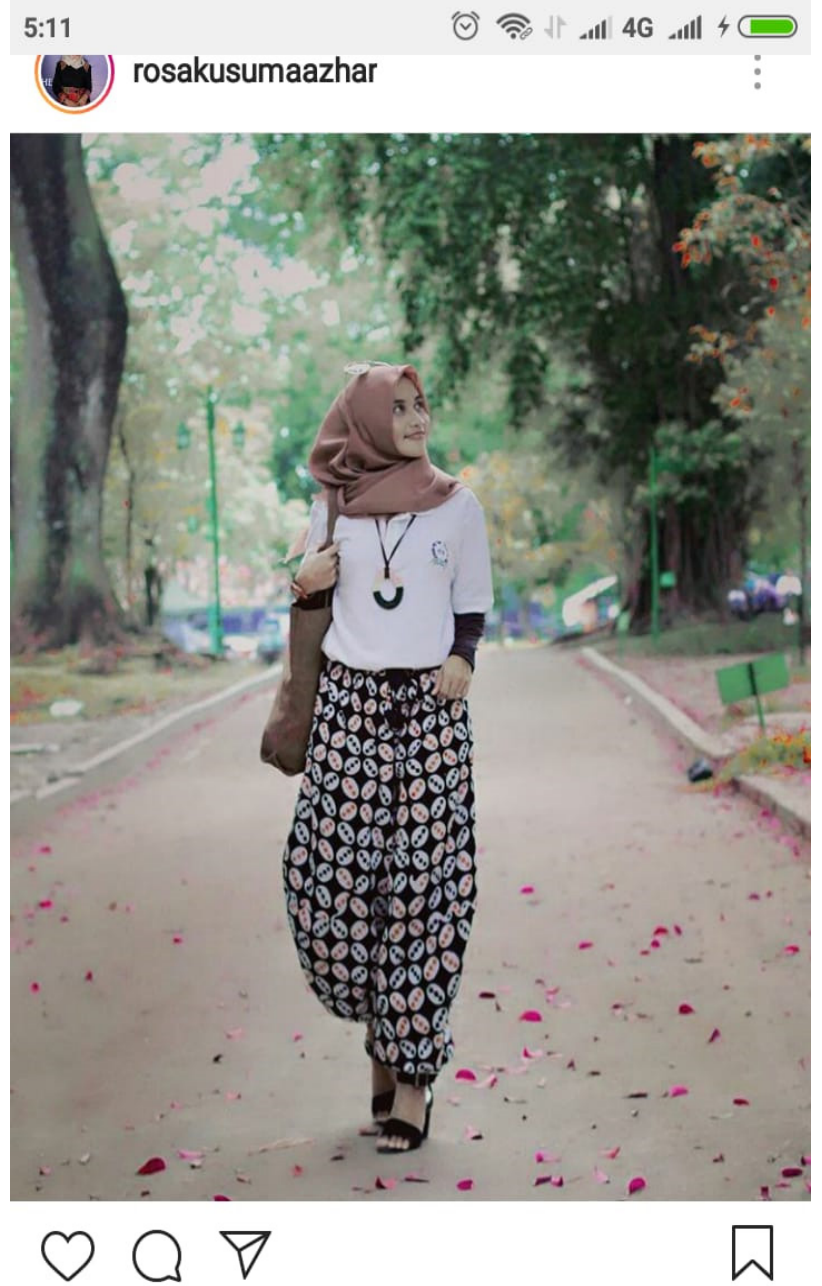

Liked by herni_maryuliani and $\mathbf{3 5 5}$ others

rosakusumaazhar Walk lightly, through life ...

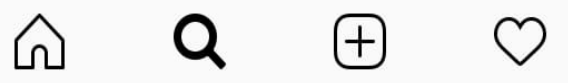

Gambar 5 Akun@rosakusumaazhar mevisualisasikan dirinya

berat badan ketika dalam berumah tangga akan berarti mengganggu cara kerja hubungan seksual suami-istri. Sehingga relasi intim suami istri banyak direproduksi oleh daya kontrol untuk tetap mempertahankan bentuk langsing dan seksi sebagai satu-satunya daya pikat. Tubuh menjadi media komunikasi bahwa saya masih energik-saya masih sangat sehat untuk beraktivitas lebih dari yang saya perlihatkan.

Visualisasi penuh aktivitas dan tubuh ramping menjadi simbol wanita yang indah dan cantik ditegaskan dengan teks atau caption yang dibuat Rosa. Keyakinan tentang kecantikan wanita sebagai sifat feminin telah berakar dalam sistem sosial yang lebih luas dan terprogram secara budaya (Melliana, 2006). Karena memang semenjak usia dini, perempuan diajarkan untuk menganggap penampilan 
fisik sebagai salah satu faktor penting dalam menumbuhkan kebanggaan dan rasa percaya diri. Makna itu tertampil dalam unggahan Rosa.

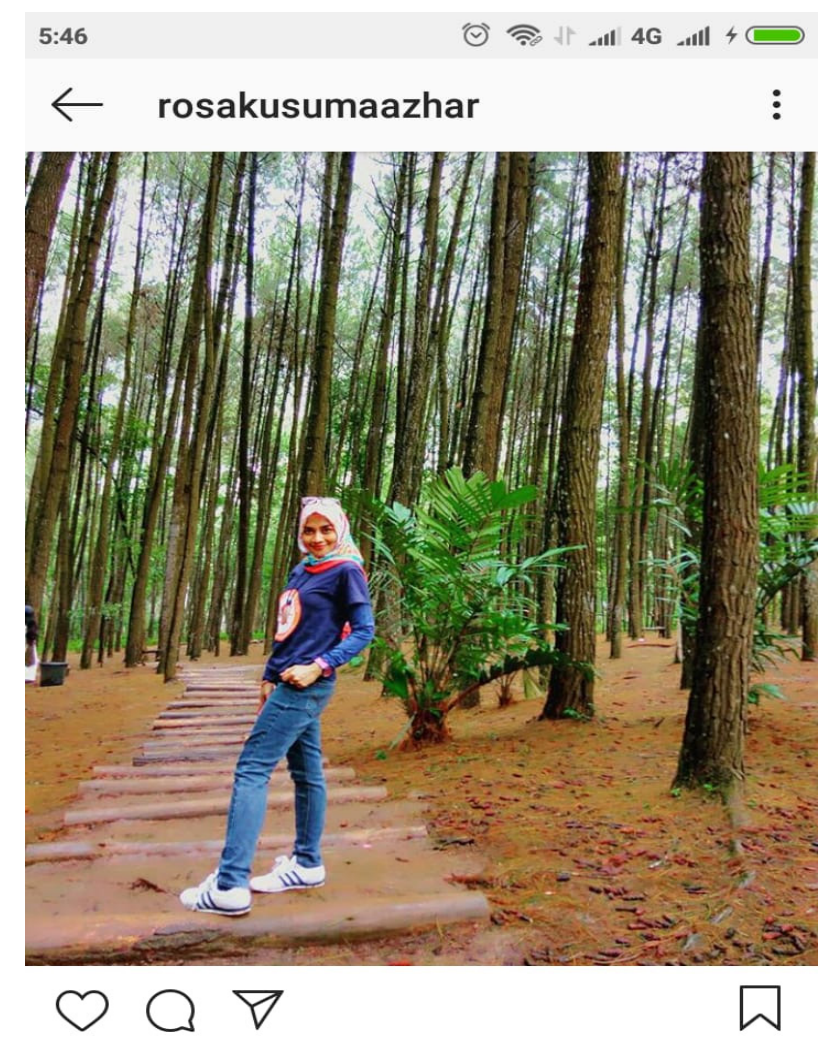

Liked by barafmjogja and 132 others

rosakusumaazhar All days wake up blessed ... Breath is the link between mind and body ...

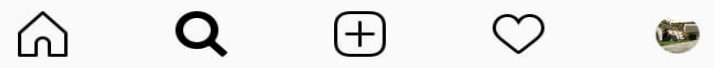

\section{Gambar 6 Akun@rosakusumaazhar memvisualkan mind and body}

Anggapan tubuh yang cantik itu harus ramping dan indah diperkuat dengan dongengdongeng yang dibangun semenjak anakanak wanita belajar, dongeng Timun Mas atau Bawang merah dan Bawang Putih sepertinya memberi pesan kepada anak-anak wanita ini mereka harus cantik untuk disukai. Belajar dengan cantik dan ramping yang bisa mendapatkan pangeran yang gagah dan kaya, bahkan tampan. Jadi, sebaliknya jika tidak memberikan diri cantik dan ramping mereka tidak bisa mendapatkan pangeran yang seperti itu. Saat melakukan aktivitas inilah pemilik akun membangun jaringan melihat foto-foto yang diunggahnya dikonsumsi, membuat pertemanan, mengekspresikan dirinya secara virtual.@rosakusumaazhar merasakan keberadaan tubuh dan identitasnya menjadi sesuatu yang bisa dikreasikan, oleh karena itu ia menggunakan aplikasi editing, karena aplikasi ini mudah dioperasikan oleh siapapun di dunia maya, di dunia maya semua bisa saja dibentuk bahkan bisa berbeda dengan kenyataannya. Sebagai manusia virtual, @rosakusumaazhar hanya menjadi atribut atau topeng dengan segala aturan, kemampuan, dan perolehan yang ditentukannya sendiri. Tim Jordan mengatakan bahwa tiga elemen dasar kekuatan individu di dunia maya adalah adanya, identity fluidity, renovated hierarchies, information as reality. Identity fluidity (Taylor \& Jordan, 2002), bermakna sebuah proses pembentukan identitas secara online atau virtual yang terbentuk tidaklah mesti sama atau mendekati dengan identitas di dunia nyata (offline identities) terlihat dalam unggahan foto yang tubuh masih menggunakan "asli" bukan rekayasa-visual manipulation. Renovated hierarchies adalah proses dimana hirarki-hirarki yang terjadi di dunia nyata di reka bentuk kembali menjadi online hierarchies. Bahkan dalam praktiknya Tim Jordan mendefinisikan istilah ini dengan anti hierarchical. Hasil akhir dari identity fluidity dan renovated hierarcies inilah yang selanjutnya disebut informational space, yakni informasi yang menggambarkan realitas yang berlaku di dunia nyata. "just now everybody wants to talk about 'identity'... identity only becomes an issue when it is crisis, when something assumed to be fixed, coherent and stableis displaced by the experience of doubt and uncertainty" (Woodward \& Hoyne, 1999) Instagram membuat ruang penggunanya semakin bisa leluasa membuat siapakah dirinya sama-berbeda-bahkan fantasi tentang mereka, media sosial ini memberi keleluasaan dengan sumber daya-kemampuan dalam mengolah foto untuk media presentasi-representasi.

Fantasi tubuh yang diberikan dari akun @rosakusumaazhar adalah fantasi yang menciptakan. fantasinya menambah bayanganbayangan atau tanggapan-tanggapan bagaimana cantik dan ramping yang dia punya sebenarnya, sehingga dengan demikian akan menambah bahan bayangan yang ada pada visualisasi yang diberikan Rosa. Wacana Ramping yang dihadirkan Rosa senantiasa melibatkan kondisi sosial dalam memproduksi dan menafsirkannya. Kondisi-kondisi foto unggahan di Instagram dari akun@rosakusumaazhar terkait erat dengan tiga tataran organisasi sosial dalam wacana: situasi sosial, institusi sosial dan tataran sosial secara 


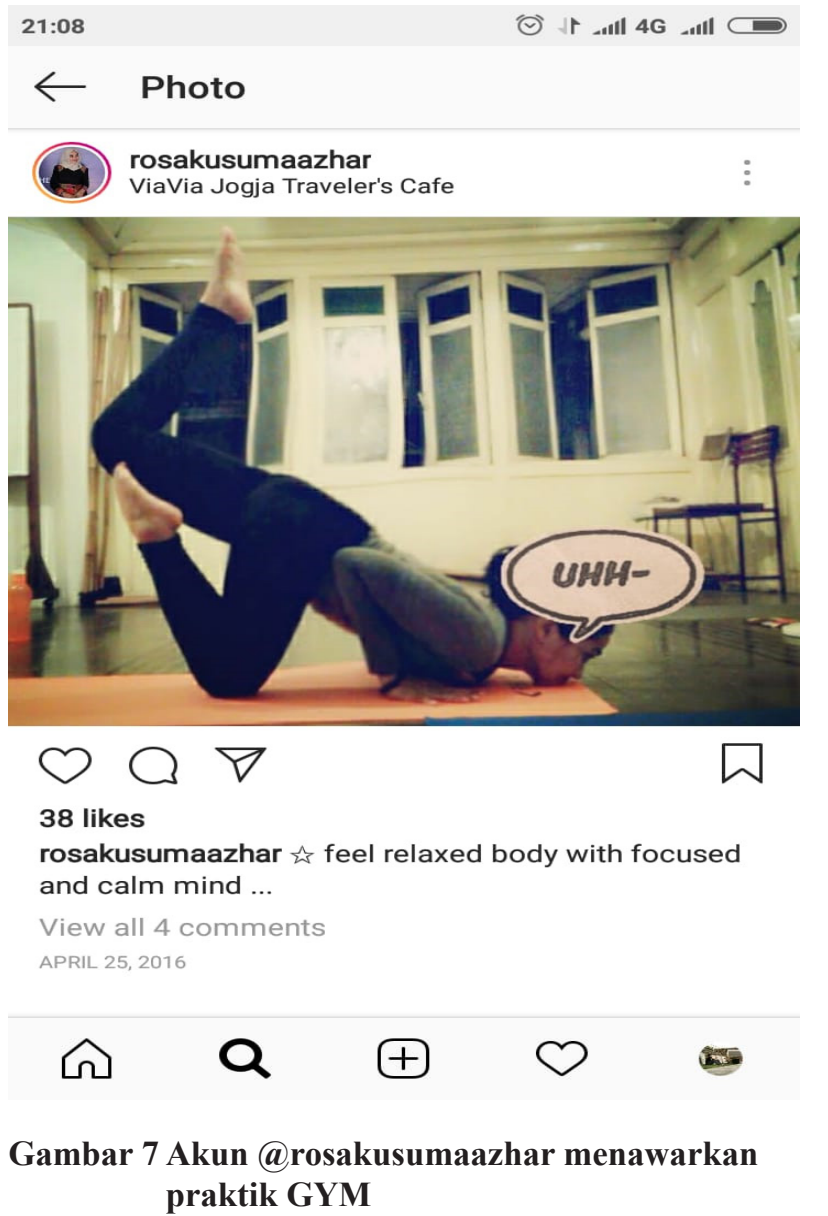

umum. Dalam konstruksi sosial yang terbangun ini, perwujudannya terlatarbelangi berdiri kuat ideologi kapitalisme dan konsumerisme melalui media dengan mengusung tema kecantikan dan kesehatan menawarkan berbagai cara, strategi dan juga produk yang digunakannya untuk mendisiplinkan tubuh.

Rampingnya Rosa dalam unggahan foto di IG yang dimilikinya, mewacanakan wanita yang indah tidak sekedar cantik, halus tutur bahasanya, sopan bahkan manja. Tetapi juga dia pintar, kreatif atau pemberani. Visualisasi buku dan membaca mempertegas wanita pintar itu berdekatan dengan buku dan membaca. Wacana itu ditampilkan dalam unggahan foto pada gambar 8 .

Institusi sosial di lingkungan Rosa mengonstruksi itu semua, dalam bahasa Bourdieu struktur kelas sosial yang dimiliki @)rosakusumaazhar melakukan diferensiasi sebagai arena pertarungan simbolik karena sebagai disposisi yang dimiliki untuk bisa membedakan dan mengapresiasi, selera merupakan praktik yang diorientasikan oleh habitus kelas. Sebagai praktik yang diorientasikan oleh habitus kelas, Bourdieu menyatakan bahwa:
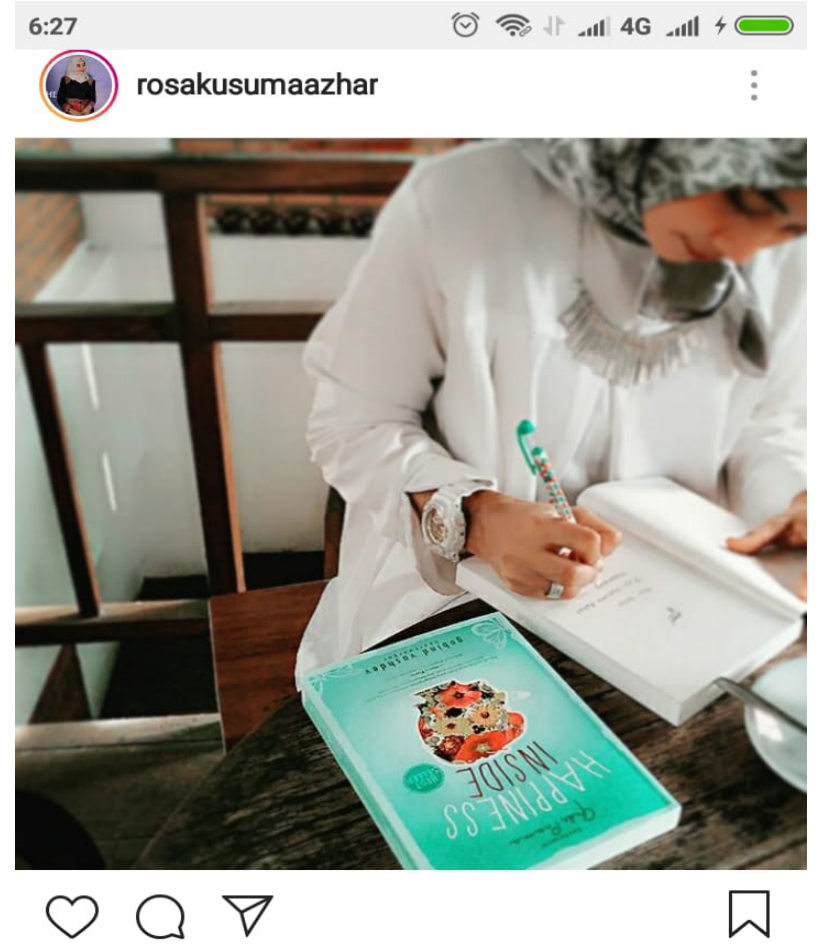

Liked by herni_maryuliani and $\mathbf{2 8 3}$ others

rosakusumaazhar $\sim$ Kehidupan merupakan sebuah bacaan yang tidak kita ketahui bagaimana babak terakhirnya .......

View all 15 comments

NOVEMBER 14, 2017

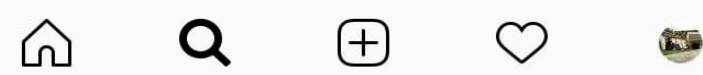

Gambar 8 Akun@rosakusumaazhar memvisualkan diri itu pintar dan kreatif

..its perhaps immoderate ambition of giving a sientific answer to the old questions of Kant's critique of judgement, by seeking in the structure of social class the basis of the systems of clasification which structure perception of the social world and designate the object of aetshetic enjoyment (Bourdieu, 2015).

Pernyataan ini ditegaskan dalam buku Distinction: A Social Critique of the Judgement of Taste. Karena itu di dalam Distinction Bourdieu mendefinisikan selera secara spesifik sebagai keahlian praktis (practical mastery) hasil dari distribusi yang memungkinkan seseorang merasai (to sense) dan mengintuisi (intuit) apa yang memungkinkan atau tidak memungkinkan seseorang menempati posisi tertentu di dalam ruang sosial. Artinya bahwa selera berfungsi sebagai orientasi sosial, atau sebagai semacam rasa tentang posisi (sense of one's place), yang membimbing agenagen seperti@rosakusumaazhar menempati 
posisi tertentu di dalam ruang sosial untuk menyesuaikan sifat-sifat mereka terhadap posisinya serta memilih praktik ataupun bendabenda budaya yang selaras dengan posisinya di dalam ruang sosial.

Cantik menjadi perwujudan dalam aktivitas wanita masa kini. Setiap sudut ruang publik yang diakses@rosakusumaazhar selalu disodorkan perayaan dan wacana kecantikan masa kini. Mulai dari promosi produk kosmetik, alat peraga body language untuk merampingkan tubuh, pameran-pameran atau acara selalu selalu menghadirkan citra tubuh perempuan yang cantik melalui wanita berbalut sales promotion girls. Kecantikan menjadi panorama hasrat publik dalam mencitrakan perempuan. Yang cantik telah menggerakkan vitalitas kehidupan dan memberi kapasitas beragam makna yang menjawab prinsipprinsip kesenangan. Hal tersebut sekaligus mengimplikasikan antisipasi praktis atas makna sosial dari pilihan-pilihan kelompok agen sosial lain (Bourdieu, 1984). Ruang publik yang dikonsumsi@rosakusumaazhar turut memberikan arah konstruksi sosial yang dibangun Rosa, membangun perwujudan kolektif dan menjadi fantasi, kemampuan jiwa untuk membentuk tanggapan-tanggapan atau bayangan-bayangan baru mengenai cantik yang indah tetapi juga kreatif dan pintar.

\section{SIMPULAN}

Dua akun yang diteliti@putrilellyana dan @rosakusumaazhar menghadirkan banyak tentang wacana wanita mengenai tubuh mereka. Dua akun ini secara ekonomi dan pendidikan sangatlah cukup karena berada dalam kelas menengah, daya kritis dimiliki kedua akun cukup memadai diwujudkan dalam caption-caption yang mereka buat terlihat dalam feed yang mereka miliki. Kenyataan yang termanifestasi dalam dua akun ini bahwa konsumsi dan produksi dalam arena Instagram memberikan pembentukan pola realitas sosial. Instagram bisa menjadi alat efektif pembentuk konstruksi sosial, sekaligus pembentuk wujud kuasa kebenaran dalam realitas sosial, Instagram sanggup membuat ruang kendali untuk mewujudkan keseragaman norma-norma kehidupan. Komunikasi visual yang dihadirkan dalam ruang feed dua akun ini bercerita tentang fantasi tubuh yang sebenarnya dikendalikan
Instagram dengan berbagai sumber dayanya seperti ruang $4 \times 4$, artistik foto dan berbagai fitur editing dan filter foto yang mengharuskan foto dihadirkan harus indah. Kemampuan Instagram dalam memanipulasi foto sangat luar biasa karena aplikasi ini sangat dengan mudah di pertautkan dengan aplikasi editing apapun, karena begitu "human"nya aplikasi Instagram dalam pemakaiannya.

Instagram mewujudkan foto yang dihadirkan dalam komunikasi visual tentang tubuh "cantik dan ramping" dengan indahnya karena ada dukungan sumber daya yang dimiliki aplikasi ini. Kecantikan fisik semakin dilanggengkan sebagai daya tarik wanita yang harus dimiliki. Wanita terkuasa atas konstruksi sosial yang didukung oleh institusi sosial seperti media ini. Sehingga pemaknaan daya tarik wanita menjadi hal utama untuk mengukur kebanggaan seorang wanita dalam masyarakat semakin langgeng maknanya. Ketika produksi makna "ramping dan cantik" dilanggengkan dalam unggahan-unggahan yang ada dalam "arena" Instagram pengguna Instagram akan semakin mengukuhkannya dengan unggahan yang dimilinya juga. Maka ketika wanita berpenampilan fisik menarik atau berfantasi dalam ruang online -Instagram, hal ini juga merupakan usaha wanita agar selalu mendapatkan kesan bahwa dirinya memang pantas menikmati berbagai macam situasi yang menguntungkandalampergaulan. Dalamartikata cantik dan ramping merupakan bentuk kontrol sosial yang membangun wanita bagaimana wanita melihat dirinya dan bagaimana ia dilihat oleh orang lain. Fantasi wanita akan kecantikan fisik ini "ramping dan cantik" menambah pentingnya wacana nilai kecantikan itu sendiri. Semakin bergantung pada daya tarik fisik untuk penghargaan diri sebenarnya semakin rapuh wanita terhadap pesan-pesan budaya bahwa wanita adalah manusia yang harus otonom. Jadi Instagram melanggengkan bahwa anatomi manusia adalah takdir tetapi dapat diperbaiki di ruang Instagram untuk memperindah dalam pergaulan di masyarakat. Jadi, lingkungan sosial memberikan wujud cantik dan ramping dengan cara mengontrol makna cantik dan ramping itu sendiri, makna itu menjadi stereotip yang dianut bersama. Bahkan dalam foto dua akun itu menampilkan menjadi tetap muda dan cantik adalah keharusan dan kebenaran yang dikuatkan dengan adanya masyarakat jaringan 
dalam ruang Instagram yang memberi statement dalam bentuk komentar tentang sesuatu adalah benar atau salah di tiap unggahan. Wanita harus tetap cantik berapapun usia mereka. Menjadi tetap cantik adalah kunci dari segala kebahagiaan dalam kehidupan wanita.

Penelitian ini menghadirkan sebuah wacana bahwa wanita sebagai konsumen teknologi tidak menjadi subjek aktif dalam mengonsumsi teknologi. Penelitian ini mengharapkan adanya penelitian lanjutan yang dapat mengkaji bagaimana wanita melawan kesenangan teknologi dengan kapasitas sebagai subyek yang hadir dalam dunia teknologi. Pengaruh rentang atau kategori usia pun bisa menjadi penelitian yang dapat melengkapi penelitian lanjutan setelahnya.

\section{DAFTAR PUSTAKA}

Anderson, M. \& Jiang, J. (2018). Teen, social media \& technology 2018. Diakses dari http://www.pewinternet.org/2018/05/31/ teens-social-media-technology-2018/.

APJII. (2017). Penetrasi \& perilaku pengguna internet indonesia 2017. Asosiasi Penyelenggara Jasa Internet Indonesia.

Bell, D. (2001). An introduction to cybercultures.

Bourdieu, P. (1984). Distinction: A social critique of the judgement of taste. Paris: Les Editions de Minuit. https://doi. org/10.4324/9781315870854.

Bourdieu, P. \& Nice, R. (1990). Reproduction in education, society and culture. (R. Boyne, Ed.). London: SAGE Publications Ltd.

Bourdieu, P. (2015). Arena produksi kultural. Yogyakarta: Kreasi Wacana.

Burton, G. (2008). Yang tersembunyi di balik media (pengantar kepada kajian media). Yogyakarta: Jalasutra.

Castells, M. (2010). The rise of the network society. Massachusetts: Blackwell Publishing (2nd ed., Vol. I). United Kingdom: Blackwell Publishing Ltd. https://doi.org/10.2307/1252090

Cavallaro, D. (2000). Cyberpunk and cyberculture. Canada: Transaction Publishers.

Du Gay, P. (1996). Consumption and Identity at Work. Consumption and identity at work. London: Sage Publications Ltd.

Fairclough, N. (1989). Language and power (10th ed.). New York: Longman Group Inc.
Fairclough, N. (2013). Critical Discourse Analysis. London: Routledge.

Fardouly, J. \& Vartanian, L. R. (2017). Social Media and Body Image Concerns : Current Research and Future Directions. Current Opinion in Psychology, 9, 1-5. https://doi. org/10.1016/j.copsyc.2015.09.005.

Foucault, M. (1980). Power Knowledge: Selected Interviews and Other Writings 1972-1977. (C. Gordon, Ed.). New York: Pantheon Books.

Handaningtias, U. R., \& Agustina, H. (2017). Peristiwa Komunikasi Dalam Pembentukan Konsep Diri Communication Events in Forming the Self Concept of. Jurnal Kajian Komunikasi, 5(2), 202-209.

Herman, J. (2014). The ultimate beginner's guide to instagram. Retrieved from https://jennstrends.com/wp-content/ uploads/2014/05/The-Ultimate-BeginnersGuide-To-Instagram.pdf.

Heryanto, A. (2000). Kelas menengah indonesia. pdf. Tempo, pp. 142-143.

Lim, F. (2008). Filsafat teknologi/don ihde tentang dunia, manusia dan alat. Yogyakarta: Kanisius.

Jang, J. Y., Han, K., Shih, P. C., \& Lee, D. (2015). Generation like: comparative characteristics in instagram. Acm Chi, (October), 4039-4042. https://doi. org/10.1145/2702123.2702555.

Kertamukti, R. (2013). Komunikasi simbol: peci dan pancasila. Profetik Jurnal Komunikasi, 6(1), 53-66.

Lechte, J. (2008). Fifty key contemporary from structuralism to post-humanism second edition. London: Routledge.

Melliana.(2006). Menjelajah tubuh: perempuan dan mitos kecantikan. Yogyakarta: LKis.

Naseh, M. V. (2016). Person and personality in cyberspace. Masaryk University Journal of Law and Technology, 10(1), 1-21. https:// doi.org/10.5817/MUJLT2016-1-1.

Ningrum, V., Putri, I. A. P., \& Ekaputri, A. D. (2015). Penduduk muda kelas menengah, gaya hidup, dan keterlibatan politik: studi empiris perkotaan di jabodetabek. Conference: Seminar Ilmiah Kependudukan "Kependudukan untuk Pembangunan Pasca 2015” (pp. 1-20). Jatinangor, West Java: Padjadjaran University. Diakses dari https://www.researchgate. 
net/publication/289970139_Penduduk Muda_Kelas_Menengah_Gaya_Hidup_ dan_Keterlibatan_Politik_Studi_Empiris_ Perkotaan_di_Jabodetabek_Young Middle_Class_Population_Lifestyle_ and_Political_Participation_Empirical_ Evidence_from_urban.

Prabasmoro, A. P. (2006). Kajian budaya feminis: tubuh, sastra, dan budaya pop. Yogyakarta: Jalasutra.

Rahmanita, U. (2015). Perbedaan kecenderungan harsistik antara laki-laki dan perempuan pengguna jejaring sosial instagram. Jurnal Hasil Riset.

Taylor, T. L., \& Jordan, T. (2002). Cyberpower: the culture and politics of cyberspace and the internet. Contemporary Sociology (Vol. 31). https://doi.org/10.2307/3089671.

Thahir, A. (2014). Psikologi belajar.

Weeks, J. (2002). Sexuality and its discontent: meaning, myths and modern sexualities. London: Routledge.

Woodward, A. L., \& Hoyne, K. L. (1999). Infants' learning about words and sounds in relation to objects. Child Development, 70(1), 65-77. https://doi.org/. 